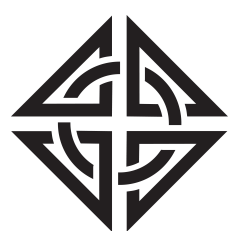

SCIENTIA

I RA N I C A
Sharif University of Technology

Scientia Iranica

Transactions C: Chemistry and Chemical Engineering

www.scientiairanica.com

\title{
Comparison and optimization of conjugated linoleic acid production by Lactobacillus plantarum and Lactobacillus plantarum subsp. plantarum
}

\author{
Z. Kouchak Yazdi, I. Alemzadeh* and M. Vossoughi \\ Department of Chemical and Petroleum Engineering, Sharif University of Technology, Tehran, Iran.
}

Received 6 February 2016; received in revised form 4 October 2016; accepted 27 December 2016

\author{
KEYWORDS \\ Conjugated linoleic \\ acid; \\ Castor oil; \\ Lactobacillus \\ plantarum; \\ Optimization; \\ Washed cell.
}

\begin{abstract}
Conjugated Linoleic Acid (CLA) was produced from castor oil using washed cells of Lactobacillus plantarum PTCC 1058 and Lactobacillus plantarum subsp. plantarum PTCC1745 as the catalyst. Under the optimal reaction conditions, the washed cells of Lactobacillus plantarum PTCC1058 produced $1661.26 \mathrm{mg}$ of CLA/L reaction mixture $(36 \%$ yield of production) from $4.6 \mathrm{mg} / \mathrm{ml}$ of castor oil after using $15 \%(\mathrm{w} / \mathrm{v})$ cell for $121 \mathrm{~h}$. The resulting CLA was a mixture of two CLA isomers, cis-9, trans-11 (or trans-9, cis11)-octadecadienoic acid (CLA1, 44\% of total CLA) and trans-10, cis-12-octadecadienoic acid (CLA2, 46\% of total CLA). The total production of CLA is extracellular in all of the reactions performed with Lactobacillus plantarum PTCC1058. Also, Lactobacillus plantarum PTCC1745 produced $1590.31 \mathrm{mg}$ of CLA/L reaction mixture (16.5\% production yield) from $9.6 \mathrm{mg} / \mathrm{ml}$ of castor oil after using $15 \%(\mathrm{w} / \mathrm{v})$ cell for $121 \mathrm{~h}$. Therefore, Lactobacillus plantarum PTCC1058 was suggested for CLA production due to its more production ability and CLA extracellular production.
\end{abstract}

(C) 2017 Sharif University of Technology. All rights reserved.

\section{Introduction}

Pharmaceutical and chemical industries used Lactic acid bacteria widely in foods and drugs. Lactobacillus plantarum is one of the strains of Lactic acid bacteria capable to produce nutritious and valuable products such as Conjugated Linoleic Acid (CLA). CLA is a natural derivative of the essential fatty acid (linoleic acid) and has received increasing attention in recent years due to its health effects potential [1], such as having anticarcinogenic activity [2-4], enhancing the immune system, or decreasing body fat content [5]. CLA is not a single substance but actually a mixed group of positional and geometrical isomers of linoleic

*. Corresponding author. Tel.: +98 2166164102

E-mail addresses: zahrayazdi@che.sharif.ir (Z. Kouchak

Yazdi); alemzadeh@sharif.ir (I. Alemzadeh);

Vossoughi@sharir.ir (M. Vossoughi)
acid(C18:2) - conjugated double bonds position may vary from 7 to 14 carbon atoms - including all possible geometric configurations of trans-cis, cis-trans, ciscis, and trans-trans isomers [6,7]. The major isomer present in food ( $>80 \%)$, such as beef, milk, and dairy products, is cis- 9 , trans-11 CLA; therefore, the majority of the research has focused on the cis-9, trans-11 CLA. Moreover, the c9, t11 CLA has been associated with a multitude of health promoting effects, such as anti-atherogenic activity [8].

Other isomers, namely, trans-10, cis-12 (t10, c12 CLA), are found in much smaller quantities. c9, t11 CLA and t10, c12 CLA are considered to be the most bioactive isomers $[1,9]$. However, the low concentration of CLA found in these food products does not seem to be sufficient to have any significant therapeutic effect and, thus, efforts are running in order to obtain CLA-enriched foods [1]. Using CLA for medicinal and food purposes requires a safe and selective process. 
The use of biological reactions to produce CLA is recommended. Nowadays, CLA is applicable in food products and is usually produced by chemical synthesis method. One of the disadvantages of chemical synthesis method is production of various isomers. From this point of view, the biotechnological techniques and the use of microorganisms are highly considered because of the minimum production of byproducts as well as outputting of natural products. Compared to the formation of CLA in the rumen, bacterial synthesis of CLA by the biotechnological process has a number of advantages, such as independence from atmospheric conditions and season of the year, the possibility of accurate monitoring of the process, and the possibility of a continuous production. The bacteria that have common and well-known culture conditions and are Generally Recognized As Safe (GRAS) are especially attractive [10]. An excellent review of the microbial synthesis of CLA was presented by Ogawa et al. [11]. The findings of Ogawa et al. led to the establishment CLA production by lactic acid bacteria from ricinoleic acid and, furthermore, from castor oil [11]. Only two CLA isomers, c9, t11(CLA1) and t10, c12CLA(CLA2), were produced from ricinoleic acid or castor oil by lactic acid bacteria, suggesting that the biological CLA production processes are more isomerselective than the chemical ones [11]. Ricinoleic acid is abundant in plant oil and castor oil. Castor oil is an economical source of ricinoleic acid. About $88 \%$ of the total fatty acids in castor oil is ricinoleic acid. However, CLA was produced from castor oil in an unexpected low yield [12]. Lactic acid bacteria were found to only use the free form of ricinoleic acid for CLA production, not its triacylglycerol form, which is mainly found in castor oil. Thus, Ando et al. (2004) investigated the conditions for practical CLA production from castor oil in the presence of lipase with Lactobacillus plantarum JCM 1551 to increase CLA productivity [13].

In this research, the washed cells of Lactobacillus plantarum PTCC 1058 and Lactobacillus plantarum subsp. plantarum PTCC1745, which have the potential for CLA synthesis, were employed as the catalyst for CLA production. Three main factors including cell concentration, substrate concentration, and cultivation time, which could impact the yield and amount of CLA production, were also studied.

\section{Materials and methods}

\subsection{Materials}

Lactobacillus plantarum PTCC 1058 and Lactobacillus plantarum subsp. plantarum PTCC1745 were obtained from Iranian Research Organization for Science and Technology Co. (Tehran, Iran); and Lipase enzymes were obtained from Merck (Lipase 24548, Native lipase from Chromobacterium viscosum, Germany) and Renco (Lipase 20522.6, New Zealand). Castor oil (triacylglycerol: ricinoleic acid $89.1 \%$ ) and standard fatty acids methyl ester CLA (FAME) (c9, t11octadecadienoic acid 42\%, t10, c12 octadecadienoic acid 44\%, c10 c12-octadecadienoic acid 10\%, and others $5 \%$ ) and linoleic acid (c9, c12-octadecadienoic acid) were purchased from Sigma (St. Louis, MO). Methanolic boron trifluoride was supplied by Fluka (Switzerland). Tween 80 and all other chemicals were of analytical grade and from Merck (Darmstadt, Germany).

\subsection{Microorganisms, cultivation, and preparation of washed cells}

Lactobacillus plantarum PTCC 1058 and Lactobacillus plantarum subsp. plantarum PTCC1745 were selected as potent CLA producers from ricinoleic acid and utilized in this study. The strains were cultivated in MRS broth medium at $37^{\circ} \mathrm{C}$ for $24 \mathrm{hr}$, the medium was supplemented with $0.04 \%(\mathrm{w} / \mathrm{v})$ linoleic acid. Cells were harvested by centrifugation (4000 rpm, 10 min), washed twice with physiological serum $0.85 \%$, centrifuged again, and then used as the washed cells for the cultivations.

\subsection{Reaction conditions}

The reaction mixture, $1 \mathrm{ml}$ in a $25 \mathrm{ml}$ Flask, comprised $10.0,15.0$, and $20.0 \mathrm{mg} / \mathrm{ml}$ castor oil mixed with Tween $80(0.1 \% \mathrm{w} / \mathrm{v}), 0.5 \mathrm{M}$ phosphate buffer ( $\mathrm{pH} 6.5), 100$ $\mathrm{U} / \mathrm{ml}$ lipase, and 10, 15, 20\% (wet cell w/v) washed cells. The cultivations were carried out with Gentle shake and $120 \mathrm{rpm}$ at $37^{\circ} \mathrm{C}$ for 72,120 , and $170 \mathrm{hr}$.

\subsection{Lipid extraction and analyses}

Lipid extraction was performed by the methods of Bligh and Dyer [14], followed by incubation; the medium was mixed with $7.5 \mathrm{ml}$ of chloroform: methanol $(2: 1, \mathrm{v} / \mathrm{v})$ and shaked for $1 \mathrm{~min}$. Then, $2.5 \mathrm{ml}$ of chloroform was added to the solution and shaked for $1 \mathrm{~min}$. After that, $2.5 \mathrm{ml}$ of deionized water was added and shaked for $1 \mathrm{~min}$, and the mixture was centrifuged at $4000 \mathrm{rpm}$ for $15 \mathrm{~min}$. To study the intracellular production of CLA, cells were collected and stored in phosphate buffer solution [15].

The lower layer was transferred to a $50 \mathrm{ml}$ balloon and evaporated with a rotary evaporator at $30^{\circ} \mathrm{C}$. The residue was saponified with $1 \mathrm{ml}$ of $1.0 \mathrm{~N}$ sodium hydroxide in methanol in a $100^{\circ} \mathrm{C}$ water bath for $15 \mathrm{~min}$. As described in the methylation procedures, Chin et al. used acid catalyzed methanolysis; $6 \mathrm{ml}$ of $4 \% \mathrm{HCl}$ in methanol was added after cooling and methylated at $60^{\circ} \mathrm{C}$ for $20 \mathrm{~min}$ [16]. The mixture was concentrated under a stream of nitrogen at room temperature and redissolved in $3 \mathrm{ml}$ of hexane. Finally, CLA in hexane extract was quantified by capillary GC MSD. GC MSD analysis instrumentation used for the analyses was as follows: Agilent 5975c (Agilent Technologies, Santa 
Clara, CA, United States of America) equipped with Hp-5 MS fused silica capillary column $(30 \mathrm{~m}, 0.32 \mathrm{~mm}$ i.d., $0.25 \mu \mathrm{m}$ film thickness). The injection volume was $1.0 \mu \mathrm{l}$. The temperature of the $\mathrm{GC}$ oven was programmed at $110^{\circ} \mathrm{C}$ for 2 min and from $110^{\circ} \mathrm{C}$ to $230^{\circ} \mathrm{C}$ was programmed at the rate of $5^{\circ} \mathrm{C} / \mathrm{min}$ and held for $5 \mathrm{~min}$, then from $230^{\circ} \mathrm{C}$ to $270^{\circ} \mathrm{C}$ was also programmed at the rate of $10^{\circ} \mathrm{C} / \mathrm{min}$ and held for 5 $\min$. The injector and detector temperatures were $270^{\circ} \mathrm{C}$. Helium was used as the carrier and make-up gas. The flow rate of make-up gas was $30 \mathrm{ml} / \mathrm{min}$. The pressure was maintained at $10 \mathrm{psig}$ on the column in order to obtain the flow rate of the carrier gas at $1.2 \mathrm{ml} / \mathrm{min}$. The split ratio was set at 1:100. The c-9, t-11 CLA methyl ester eluted for 23.14 min was identified by comparing the retention time with that of methylated CLA standard (Sigma Chemical Co., St. Louis, MO, USA). To analyze the quantity of FAME, the calibration of standard methyl esters of CLA in linear correlation was illustrated with good accuracy $\left(R^{2}=0.996-9\right)$. To verify the accurate location of each fatty acid, the amount of one micro liter of standard liquids was injected to the system and retention time was set to recognize each peak.

\subsection{Optimization of processing}

Optimization of production amount and yield of CLA is the most important issue in the microbial synthesis of CLA. Thus, optimization of the process for maximum production was studied. For optimization of the process in order to maximize production yield, the surface response method was utilized. Also, planning of the tests was performed based on central composite design with three factors, each factor in 3 levels with 3 iterations in the central point containing 17 tests. Second order factorial experimental design was chosen due to its capability to save time and work (minimizing the number of performed experiments) [17]. The quantities of independent variables consisting of oil concentration $(\mathrm{mg} / \mathrm{ml})$, cultivation time $(\mathrm{hr})$, and the quantity of cells (\%) were converted to the encrypted codes $+1,0,-1$ that represented high, medium, and low levels, respectively, which are presented in Table 1 [18].
For the statistical analysis, consisting of regression, variance analysis, the graphical shapes, and optimization, design expert 8 software was used [19]. The yield of CLA production was evaluated with the following equation:

yield of CLA production $=$

$$
\frac{\text { CLA concentration }}{\text { Castrol oil concentration }} * 100 \text {. }
$$

Polynomial models were used for adjusting of experimental data [17]:

$$
Y=a_{0}+\sum_{i=1}^{3} a_{i} X_{i}+\sum_{i=1}^{3} a_{i i} X_{i}^{2}+\sum_{i<j} a_{i j} X_{i} X_{j}
$$

where $Y$ represents each of the system responses (dependent variables) studied; $X_{i}$ and $X_{j}$ are the independent variables defined in Table 1 ; and $a_{0}, a_{i}$, and $a_{i j}$ are the fitting parameters (obtained by multiple regression).

\section{Results and discussion}

According to the research [1,11], Lactobacillus plantarum has the highest CLA production; therefore, in this study, washed cells of Lactobacillus plantarum PTCC1058 and Lactobacillus plantarum subsp. plantarum PTCC1745 were selected to study CLA production. Using resting cells (washed cells) of lactic acid bacteria helped to avoid cell growth inhibitory effect of unsaturated fatty acids such as linoleic acid.

In Figure 1, the growth curves of Lactobacillus plantarum in MRS medium and MRS medium with $0.04 \% \mathrm{LA}$ are presented. The maximum CLA production occurred in the beginning of stationary phase of Cell growth. After $24 \mathrm{hr}$ of growth, the cells were collected and transferred into MRS medium with $0.04 \%$ LA for $24 \mathrm{hr}$, leading to adaptation of cells with LA. As it is presented in Figure 1, when bacteria are grown in MRS medium with $0.04 \%$ linoleic acid, it reaches the stationary phase in a shorter time.

\begin{tabular}{|c|c|c|c|c|c|c|c|}
\hline \multirow{2}{*}{$\begin{array}{c}\text { Independent } \\
\text { variables }\end{array}$} & \multirow[t]{2}{*}{ Sy mbols } & \multicolumn{3}{|c|}{$\begin{array}{c}\text { Variable levels } \\
\text { encrypted for } \\
\text { L.P.1058* }\end{array}$} & \multicolumn{3}{|c|}{$\begin{array}{c}\text { Variable levels } \\
\text { encrypted for } \\
\text { L.P.1745* }\end{array}$} \\
\hline & & -1 & $\mathbf{0}$ & +1 & -1 & 0 & +1 \\
\hline Cultivation time (hr) & $X_{1}$ & 72 & 121 & 170 & 72 & 121 & 170 \\
\hline Quantity of cell (\%) & $X_{2}$ & 10 & 15 & 20 & 10 & 15 & 20 \\
\hline Oil concentration $(\mathrm{mg} / \mathrm{ml})$ & $X_{3}$ & 5 & 10 & 15 & 10 & 15 & 20 \\
\hline
\end{tabular}

Table 1. Independent variables and their levels for the combinational central plan in CLA production process. 


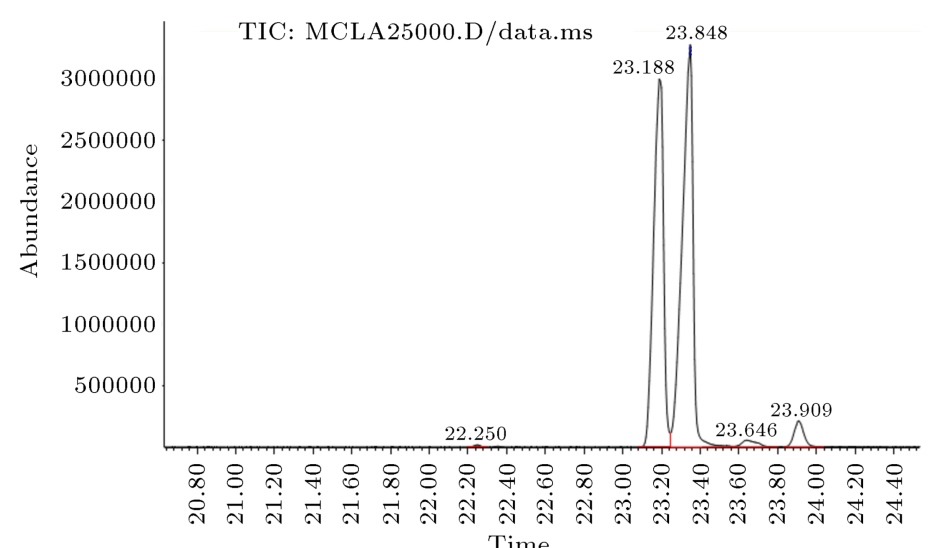

(a)

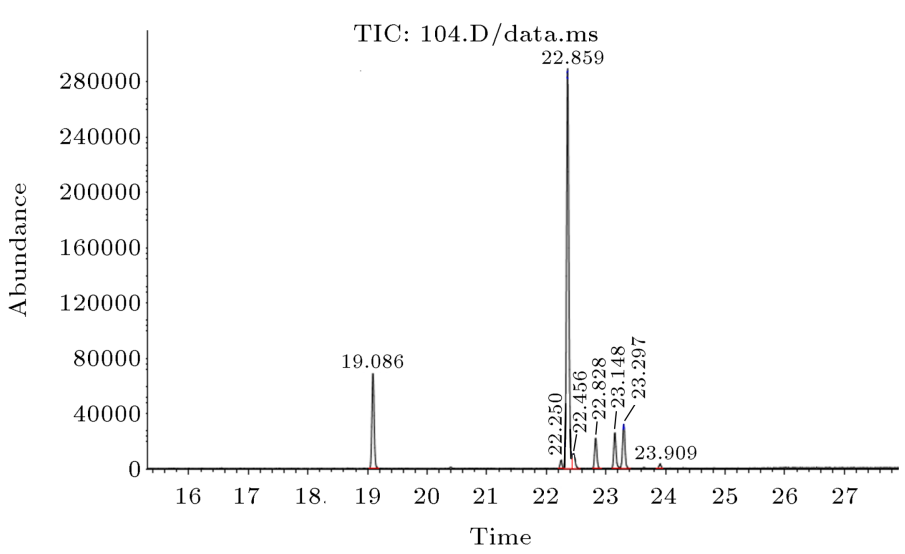

(b)

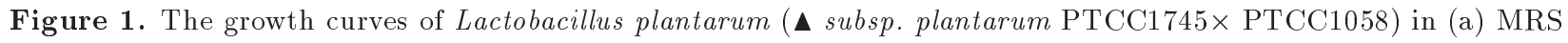
medium and (b) MRS medium with $0.04 \%$ LA.

Table 2. Specific growth rate of lactobacillus strains in MRS medium and MRS with linoleic acid.

\begin{tabular}{cccccc}
\hline & \multicolumn{2}{c}{ MRS } & \multicolumn{2}{c}{ MRS+LA } \\
\hline Strain & $\mu\left(h^{-1}\right)$ & $R^{2}$ & $\mu\left(h^{-1}\right)$ & $R^{2}$ \\
Lactobacillus plantarum PTCC1745 & 0.349 & 0.96 & 0.4457 & 0.790 \\
Lactobacillus & plantarum PTCC1058 & 0.320 & 0.992 & 0.124 & 0.999 \\
\hline
\end{tabular}

Specific growth rates of Lactobacillus strains in MRS medium and MRS with linoleic acid are compared in Table 2. Lactobacillus plantarum PTCC1058 had less specific growth rate in MRS medium and MRS with linoleic acid, respectively.

Amount and yield of CLA production was evaluated by GC-MSD after CLA separation and free fatty acids methylation. Figure 2 shows the chromatogram of Fatty Acids Methyl Ester CLA (FAME). The maximum CLA was produced in the medium by Lactobacillus plantarum PTCC1058. After injection of methylated sample into GC-MSD, retention time for Palmitic acid, Linoleic acid, Oleic acid, Stearic acid, Cis9, trans11-CLA(CLA1), trans10, cis12-CLA(CLA2), and Ricinoleic acid methyl ester were 19.09, 22.25, 22.35, $22.82,23.14,23.3$, and 25.67 , respectively.
Design-expert software was used to optimize CLA production. Using RSM (Response Surface Method), the effects of three variables, namely, oil concentration $(\mathrm{mg} / \mathrm{ml})$, cultivation time $(\mathrm{hr})$, and the quantity of cells $(\%)$, on the amount of CLA production and yield were studied. In RSM, uncoded variables were changed to coded variables (Tables 3 and 4) with a zero mean and standard deviation that had been defined to be dimensionless. Tables 3 and 4 show experimental settings of the cultivation factors for the Central Composite Design (CCD) arrangements and responses for the CLA production yield. Also, the relation between coded independent variables and each of the system responses (dependent variables) by the method of least square multiple regressions is presented in the Table 5 . 
Table 5 shows different parameters of the models and their significance levels. $a_{2}, a_{3}, a_{12}$, and $a_{33}$ were significant parameters in the CLA production and CLA

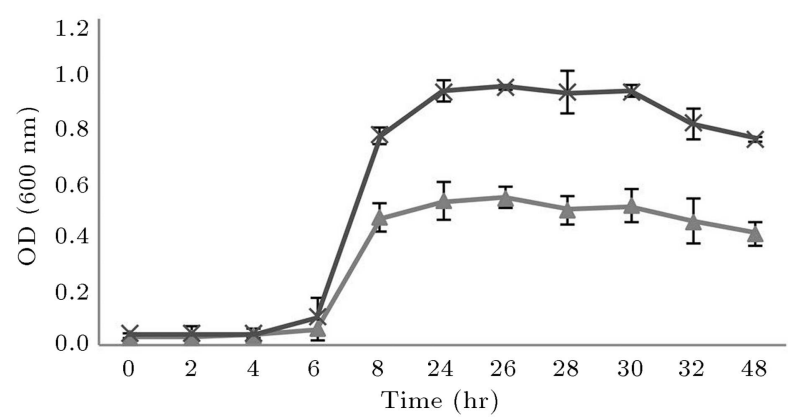

(a)

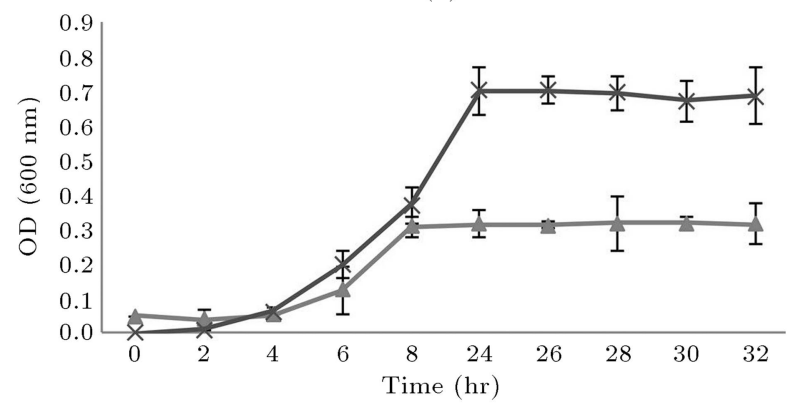

(b)

Figure 2. Chromatogram of (a) maximum CLA production by PTCC 1058 and (b) standard fatty acids methyl ester CLA (FAME) (c9, t11-octadecadienoic acid $42 \%, \mathrm{t} 10, \mathrm{c} 12$-octadecadienoic acid $44 \%$, c10

c12-octadecadienoic acid 10\%, and others $5 \%$ ). yield by PTCC1745 bacteria. $a_{1}, a_{3}$, and $a_{33}$ were significant parameters in the CLA production and CLA yield by PTCC1058 bacteria.

The results from the designed tests by Designexpert software show that for Lactobacillus plantarum PTCC1058, the production yield increased to $36.11 \%$ with decreasing oil concentration to $4.6 \mathrm{mg} / \mathrm{ml}$ and increasing cells concentration to $15 \%$ (w/v) after $121 \mathrm{hr}$. Also, for Lactobacillus plantarum subsp. plantarum PTCC1745, the production yield increased to 16.5676 with decreasing oil concentration to $9.6 \mathrm{mg} / \mathrm{ml}$ and increasing cells concentration to $15 \%$ (w/v) after $121 \mathrm{hr}$.

The production yield of Lactobacillus plantarum PTCC1058 was higher than that of Lactobacillus plantarum PTCC1745; thus, this strain had more production ability. CLA production yield increased by decreasing oil concentration as high concentration of castor oil exhibited toxic effect on cells. According to the authors' investigation, the higher efficiency in producing CLA isomers from LA confirms the hypothesis that microorganisms perform isomerization as a detoxification process because of high toxic nature of LA [20,21].

Increasing cell concentration up to $15 \%$ (w/v) was appropriate. At lower cells concentration, the quantity of cells was insufficient and castor oil showed more toxic effect on cells. At higher cells concentration, decrement in available nutrients led to lower CLA production. Reaction time effect on production and yield is presented in Figure 3. CLA production increased by increasing reaction time. However, prolonged reaction time did not increase CLA production because of detoxification

Table 3. Experimental settings of the cultivation factors for the Central Composite Design (CCD) arrangements and responses for the amounts of CLA production and yield for Lactobacillus plantarum subsp. plantarum PTCC1745.

\begin{tabular}{|c|c|c|c|c|c|c|c|}
\hline Run & $\begin{array}{c}\text { Factor } 1 \\
\text { A: time } \\
\text { hr }\end{array}$ & $\begin{array}{c}\text { Factor } 2 \\
\text { B: cell } \\
\text { concentration } \\
\% \mathrm{w} / \mathrm{v}\end{array}$ & $\begin{array}{c}\text { Factor } 3 \\
\text { C: oil } \\
\text { concentration } \\
\mathrm{mg} / \mathrm{ml}\end{array}$ & $\begin{array}{c}\text { Response } 1 \\
\text { CLA } \\
\text { concentration } \\
\mathrm{mg} / \mathrm{L}\end{array}$ & $\begin{array}{c}\text { Response } 2 \\
\text { CLA } \\
\text { yield } \\
\% \\
\end{array}$ & $\begin{array}{c}\text { CLA1 } \\
\text { concentration } \\
\mathrm{mg} / \mathrm{L}\end{array}$ & $\begin{array}{c}\text { CLA2 } \\
\text { concentration } \\
\mathrm{mg} / \mathrm{L}\end{array}$ \\
\hline 1 & 72 & 10 & 20 & 1767.15 & 8.83574 & 725.01 & 1042.11 \\
\hline 2 & 72 & 20 & 10 & 1637.71 & 16.3771 & 667.69 & 969.99 \\
\hline 3 & 121 & 15 & 15 & 1753.09 & 11.6873 & 728.85 & 1025.05 \\
\hline 4 & 173.92 & 15 & 15 & 1831.71 & 12.2114 & 751.01 & 1080.7 \\
\hline 5 & 121 & 15 & 20.4 & 1712.78 & 8.56389 & 719.3676 & 993.4124 \\
\hline 6 & 121 & 15 & 15 & 1765.31 & 11.7687 & 759.0833 & 1006.227 \\
\hline 7 & 170 & 10 & 10 & 1677.83 & 16.7783 & 687.9103 & 989.9197 \\
\hline 8 & 72 & 20 & 20 & 1784.25 & 8.92125 & 740.4638 & 1043.786 \\
\hline 9 & 72 & 10 & 10 & 1603.63 & 16.0363 & 705.5972 & 898.0328 \\
\hline 10 & 170 & 20 & 20 & 1654.18 & 8.27089 & 699.7181 & 954.4619 \\
\hline 11 & 121 & 9.6 & 15 & 1776.53 & 11.8435 & 751.4722 & 1025.058 \\
\hline 12 & 68.08 & 15 & 15 & 1734.24 & 11.5616 & 728.3808 & 1005.859 \\
\hline 13 & 170 & 20 & 10 & 1616.67 & 16.1667 & 679.0014 & 937.6686 \\
\hline 14 & 170 & 10 & 20 & 1952.29 & 9.76147 & 878.5305 & 1073.76 \\
\hline 15 & 121 & 20.4 & 15 & 1746.11 & 11.6407 & 785.7495 & 960.3605 \\
\hline 16 & 121 & 15 & 9.6 & 1590.31 & 16.5657 & 683.8333 & 906.4767 \\
\hline
\end{tabular}


Table 4. Experimental settings of the cultivation factors for the Central Composite Design (CCD) arrangements and responses for the amounts of CLA production and yield for Lactobacillus plantarum PTCC1058.

\begin{tabular}{|c|c|c|c|c|c|c|c|}
\hline Run & $\begin{array}{c}\text { Factor } 1 \\
\text { A: time } \\
\text { hr }\end{array}$ & $\begin{array}{c}\text { Factor } 2 \\
\text { B: cell } \\
\text { concentration } \\
\% \mathrm{w} / \mathrm{v} \\
\end{array}$ & $\begin{array}{c}\text { Factor } 3 \\
\mathrm{C}: \text { oil } \\
\text { concentration } \\
\mathrm{mg} / \mathrm{ml} \\
\end{array}$ & $\begin{array}{c}\text { Response } 1 \\
\text { CLA } \\
\text { concentration } \\
\mathrm{mg} / \mathrm{L} \\
\end{array}$ & $\begin{array}{c}\text { Response } 2 \\
\text { CLA } \\
\text { yield } \\
\% \\
\end{array}$ & $\begin{array}{c}\text { CLA1 } \\
\text { concentration } \\
\mathrm{mg} / \mathrm{L}\end{array}$ & $\begin{array}{c}\text { CLA2 } \\
\text { concentration } \\
\mathrm{mg} / \mathrm{L}\end{array}$ \\
\hline 1 & 72 & 20 & 5 & 1620.58 & 32.4115 & 891.319 & 939.9364 \\
\hline 2 & 121 & 15 & 15.4 & 1950.26 & 12.664 & 1107.358 & 1131.151 \\
\hline 3 & 121 & 15 & 4.6 & 1661.26 & 36.1144 & 950.7391 & 963.5308 \\
\hline 4 & 121 & 9.6 & 10 & 1612.57 & 16.1257 & 677.2794 & 935.2906 \\
\hline 5 & 72 & 10 & 5 & 1606.29 & 32.1257 & 674.6418 & 931.6482 \\
\hline 6 & 68.08 & 15 & 10 & 1615.19 & 16.1519 & 678.3798 & 936.8102 \\
\hline 7 & 72 & 10 & 15 & 1824.2 & 12.1613 & 766.164 & 1058.036 \\
\hline 8 & 121 & 15 & 10 & 1727.44 & 17.2744 & 725.5248 & 1001.915 \\
\hline 9 & 121 & 15 & 10 & 1697.44 & 16.9744 & 712.9248 & 984.5152 \\
\hline 10 & 170 & 10 & 15 & 1938.11 & 12.9207 & 814.0062 & 1124.104 \\
\hline 11 & 72 & 20 & 15 & 1814.22 & 12.0948 & 761.9724 & 1052.248 \\
\hline 12 & 173.92 & 15 & 10 & 1877.6 & 18.776 & 788.592 & 1089.008 \\
\hline 13 & 170 & 20 & 5 & 1699.6 & 33.992 & 713.832 & 985.768 \\
\hline 14 & 170 & 20 & 15 & 1872.64 & 12.4843 & 786.5088 & 1086.131 \\
\hline 15 & 170 & 10 & 5 & 1685.41 & 33.7081 & 707.8722 & 977.5378 \\
\hline 16 & 121 & 20.4 & 10 & 1740.2 & 17.402 & 730.884 & 1009.316 \\
\hline
\end{tabular}

Table 5. Regression parameters for variables, signification of regression equations and goodness of fitting.

\begin{tabular}{cccccc}
\hline $\begin{array}{c}\text { Fitting } \\
\text { parameters }\end{array}$ & \multirow{2}{*}{ Name } & $\begin{array}{c}\text { CLA } \\
\text { production 1058 }\end{array}$ & $\begin{array}{c}\text { CLA } \\
\text { yeild 1058 }\end{array}$ & $\begin{array}{c}\text { CLA } \\
\text { production 1745 }\end{array}$ & $\begin{array}{c}\text { CLA } \\
\text { yeild 1745 }\end{array}$ \\
\hline$a_{0}$ & $1722.98^{*}$ & $17.32^{*}$ & $1751.98^{*}$ & $3.42^{*}$ \\
$a_{1}$ & Cultivation time & $59.41^{*}$ & $0.69^{*}$ & $20.66^{*}$ & $0.02^{* *}$ \\
$a_{2}$ & Quantity of cell & $8.8^{* *}$ & $0.14^{* *}$ & $-33^{*}$ & $-0.029^{*}$ \\
$a_{3}$ & Oil concentration & $111.24^{*}$ & $-10.44^{*}$ & $73^{*}$ & $-0.53^{*}$ \\
$a_{12}$ & & -6.95 & -0.046 & $-51.31^{*}$ & $-0.048^{*}$ \\
$a_{13}$ & & 1.77 & -0.25 & 0.24 & $-3.08 \mathrm{E}-03$ \\
$a_{23}$ & $-12.99^{* *}$ & -0.13 & $-31.74^{* *}$ & -0.025 \\
$a_{11}$ & 15.15 & 0.038 & 29.94 & 0.022 \\
$a_{22}$ & -44.87 & -0.56 & 11.38 & $4.70 \mathrm{E}-03$ \\
$a_{33}$ & 66.05 & $5.98^{*}$ & $-82.74^{*}$ & $0.066^{*}$ \\
$R^{2}$ & 0.9144 & 0.9983 & 0.9250 & 0.9983 \\
$R^{2}(\mathrm{adj})$ & 0.8059 & 0.9958 & 0.8126 & 0.9957 \\
\hline
\end{tabular}

* Significance level $<0.05 ; * *$ Significance level $<0.10$.

mechanism of free linoleic acid. When reaction time was extended, CLA was converted to stearic acid (18:0) via trans vaccenic acid (18:1).

Optimization for maximum CLA production showed that both strains at optimum state presented similar productions and conditions (the optimum conditions and the amounts of CLA production were similar for both strains). Lactobacillus plantarum PTCC1058 produced $1938.11 \mathrm{mg}$ of CLA/L (produc- tion yield of $12.92 \%)$ at $10 \%(\mathrm{w} / \mathrm{v})$ cell concentration, $15 \mathrm{mg} / \mathrm{ml}$ of oil concentration, and $170 \mathrm{hr}$ of reaction time. Also, Lactobacillus plantarum subsp. plantarum PTCC1745 produced $1952.29 \mathrm{mg}$ of CLA/L (production yield 9.7) at $10 \%(\mathrm{w} / \mathrm{v})$ cell concentration, $20 \mathrm{mg} / \mathrm{ml}$ of oil concentration, and $170 \mathrm{hr}$ of reaction time. Therefore, Lactobacillus plantarum PTCC1058 was a better selection due to higher production yield and production concentration. 
Table 6. The comparison of CLA production with that in the other research.

\begin{tabular}{|c|c|c|c|c|c|}
\hline Strain & $\begin{array}{l}\text { Culture } \\
\text { type }\end{array}$ & Medium & Substrate & $\begin{array}{c}\text { Total } \\
\text { CLA } \\
(\mathrm{mg} / \mathrm{L})\end{array}$ & Reference \\
\hline L. plantarum A6-1F & Washed cells & $\mathrm{KPB}^{*}$ & Linoleic acid $(1.5 \mathrm{~g} / \mathrm{L})$ & 276 & [24] \\
\hline L. plantarum Ip5 & Growing cells & MRS** & Linoleic acid $(600 \mathrm{mg} / \mathrm{L})$ & 142 & {$[25]$} \\
\hline L. plantarum L12 & Growing cells & MRS & Linoleic acid $(1 \mathrm{~g} / \mathrm{L})$ & 57 & {$[26]$} \\
\hline L. plantarum JCM 1551 & Washed cells & KPB & Lipase treated castor oil $(30 \mathrm{~g} / \mathrm{L})$ & 7500 & [13] \\
\hline L. plantarum AKU 1009a & Washed cells & KPB & Ricinoleic acid $(4 \mathrm{~g} / \mathrm{L})$ & 1650 & {$[27]$} \\
\hline $\begin{array}{c}\text { Lactobacillus plantarum } \\
\text { PTCC1058 }\end{array}$ & Washed cells & MRS & Lipase treated castor oil $(4.6 \mathrm{mg} / \mathrm{ml})$ & 1661 & This work \\
\hline $\begin{array}{c}\text { Lactobacillus plantarum } \\
\text { PTCC1745 }\end{array}$ & Washed cells & MRS & Lipase treated castor oil $(9.6 \mathrm{mg} / \mathrm{ml})$ & 1590 & This work \\
\hline
\end{tabular}

Figure 3 shows the perturbation diagram for CLA yield (Figure 3(a)) and CLA concentration (Figure 3(b)) for Lactobacillus plantarum PTCC1058, which represents the effect of three coded variables on CLA yield and CLA concentration. Castor oil con-

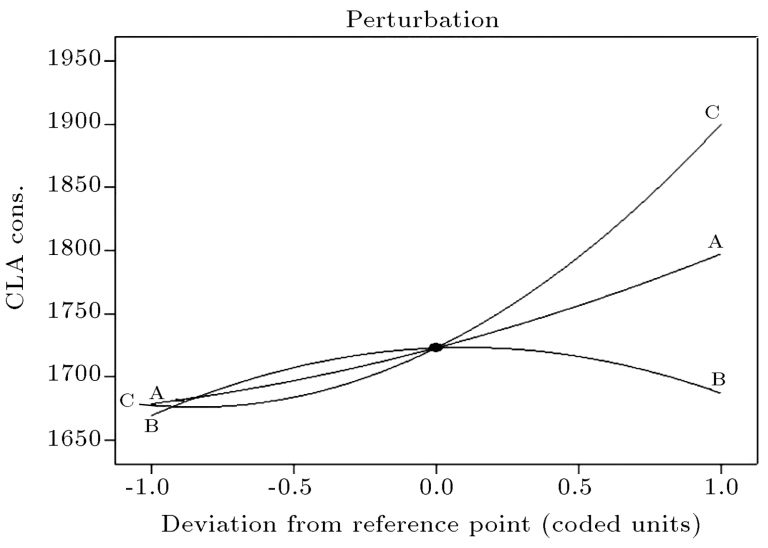

(a)

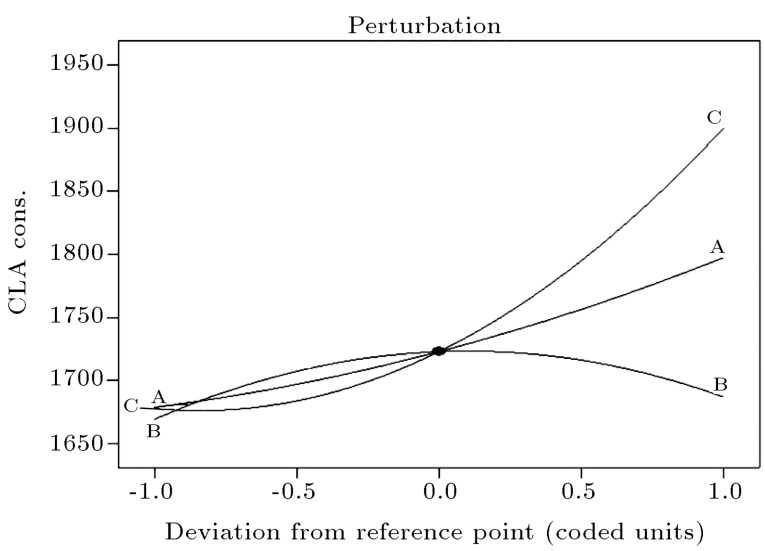

(b)

Figure 3. Perturbation diagram for CLA yield (a) and CLA concentration (b) for Lactobacillus plantarum PTCC1058 (A, B, and C are the coded variables, listed in Table 1). centration is the parameter that challenges CLA yield and CLA concentration. The higher level of castor oil increased the amount of CLA production and decreased CLA production yield. Table 6 shows the comparison of this production with that in other research. As this table presents, washed cells of Lactobacillus plantarum PTCC1058 produced a considerable amount of CLA under optimal conditions. Therefore, in order to have more attractive and economical bioconversion, the use of alternative sources of linoleic acid, such as ricinoleic, acid is desirable.

As some studies report that most of the produced CLA is associated with cells, mainly as free fatty acid [22], the intracellular CLA production has also been investigated. As shown in Table 7, under some reaction conditions with Lactobacillus plantarum subsp. plantarum PTCC1745, a significant amounts of CLA was associated with the cells. However, in all of the reactions performed with Lactobacillus plantarum PTCC1058, the CLA production was extracellular. Thus, as Lactobacillus plantarum subsp. plantarum PTCC1745 was used as the reaction catalyst, cells were broken to release the CLA associated with cells. Therefore, its use is more facile and recommended to produce extracellular CLA with Lactobacillus plantarum PTCC1058.

Two ways could be considered to produce CLA enriched foods by the use of food grade microorganisms, either as starter cultures for CLA-enriched fermented food products or as biocatalysts to produce an additive for the natural food products. The CLA produced in this study can be used as a substrate for transesterification to produce enriched triacylglycerols and neutraceutical foods $[1,23]$.

\section{Conclusion}

Using RSM (Response Surface Method), the effects of three variables, namely, oil concentration $(\mathrm{mg} / \mathrm{ml})$, 
Table 7. Intracellular and extracellular production of CLA by Lactobacillus plantarum PTCC 1058 and Lactobacillus plantarum subsp. plantarum PTCC1745.

\begin{tabular}{|c|c|c|c|c|c|}
\hline \multirow[b]{2}{*}{ Bacteria } & \multicolumn{3}{|c|}{ Reaction condition } & \multicolumn{2}{|c|}{ CLA Production } \\
\hline & $\begin{array}{c}\text { Quantity } \\
\text { of cells } \\
\% \mathrm{w} / \mathrm{v} \\
\end{array}$ & $\begin{array}{c}\text { Oil } \\
\text { concentration } \\
\mathrm{mg} / \mathrm{ml} \\
\end{array}$ & $\begin{array}{l}\text { Time } \\
(\mathrm{hr})\end{array}$ & $\begin{array}{l}\text { Intracellular } \\
\text { CLA (mg/1) }\end{array}$ & $\begin{array}{l}\text { Extracellular } \\
\text { CLA (mg/1) }\end{array}$ \\
\hline L.plantarum PTCC1058 & 15 & 10 & 68.08 & 0 & 1076.712446 \\
\hline L.plantarum РТСC1058 & 20 & 15 & 72 & 0 & 1209.305418 \\
\hline L.plantarum PTCC1058 & 10 & 15 & 72 & 0 & 1215.954572 \\
\hline L.plantarum PTCC1058 & 10 & 5 & 72 & 0 & 1070.857277 \\
\hline L.plantarum PTCC1058 & 9.6 & 10 & 121 & 0 & 1086.285531 \\
\hline L.plantarum PTCC1058 & 10 & 15 & 121 & 0 & 1101.954326 \\
\hline L.plantarum subsp. plantarum РТСC1745 & 10 & 10 & 72 & 426.25488 & 1069.011561 \\
\hline L.plantarum subsp. plantarum РТСC1745 & 15 & 9.6 & 121 & 0 & 1060.134836 \\
\hline L.plantarum subsp. plantarum РТСC1745 & 20 & 20 & 72 & 0 & 1189.340516 \\
\hline L.plantarum subsp. plantarum РТCC1745 & 10 & 20 & 72 & 0 & 1177.947408 \\
\hline L.plantarum subsp. plantarum PТCC1745 & 20.4 & 15 & 121 & 0 & 1563.652834 \\
\hline L.plantarum subsp. plantarum РТCC1745 & 15 & 15 & 121 & 623.896167 & 1076.784855 \\
\hline L.plantarum subsp. plantarum РТCC1745 & 10 & 10 & 170 & 0 & 1118.445711 \\
\hline
\end{tabular}

cultivation time (hr), and the quantity of cells (\%), on the amount of production and yield of CLA were studied. The higher level of castor oil increased the amount of CLA production and decreased CLA production yield. Under the optimal reaction conditions, washed cells of Lactobacillus plantarum PTCC1058 produced $1661.26 \mathrm{mg}$ CLA/L reaction mixture $(36 \%$ yield of production) from $4.6 \mathrm{mg} / \mathrm{ml}$ castor oil in $121 \mathrm{~h}$ by using $15 \%(\mathrm{w} / \mathrm{v})$ cell. The resulting CLA was a mixture of two CLA isomers, c9, t11octadecadienoic acid (CLA1, $44 \%$ of total CLA) and t10, c12-octadecadienoic acid (CLA2, $46 \%$ of total CLA). The total CLA production was extracellular in all the reactions performed with Lactobacillus plantarum PTCC1058. Also, Lactobacillus plantarum PTCC1745 produced $1590.31 \mathrm{mg}$ CLA/L (16.5\% yield of production) from $9.6 \mathrm{mg} / \mathrm{ml}$ castor oil in $121 \mathrm{~h}$ by using $15 \%(\mathrm{w} / \mathrm{v})$ cell. Considering higher production yield by Lactobacillus plantarum PTCC1058, this strain is suggested for CLA production as it is capable to provide higher CLA production and higher yield; therefore, this strain could be recommended for scaleup system for industrial and economical levels as the product is considered to be a functional food and a health aid.

\section{References}

1. Andrade, J.C., Ascencao, K., Gullon, P., et al. "Production of conjugated linoleic acid by food-grade bacteria: A review", International Journal of Dairy Technology, 65, pp. 467-481 (2012).

2. Hennessy, A.A., Barrett, E., Ross, R.P., Fitzgerald, G.F., Devery, R. and Stanton, C. "The production of conjugated $\alpha$-linolenic, $\gamma$-linolenic and stearidonic acids by strains of bifidobacteria and propionibacteria", Lipids, 47, pp. 313-327 (2012).

3. Pariza, M.W. and Ha, Y.L. "Newly recognized anticarcinogenic fatty acids", in Antimutagenesis and Anticarcinogenesis Mechanisms II, Ed., Springer, pp. 167-170 (1990).

4. Jafari, M., Kadivar, M., Goli, S.A.H. and Ghiaci, M. "Optimization of lipase-catalyzed fractionation of two conjugated linoleic acid (CLA) Isomers", Journal of the American Oil Chemists' Society, 91, pp. 571-578 (2014).

5. Hernández-Díaz, G., Alexander-Aguilera, A., ArzabaVillalba, A., Soto-Rodríguez, I. and García, H.S. "Effect of conjugated linoleic acid on body fat, tumor necrosis factor alpha and resistin secretion in spontaneously hypertensive rats", Prostaglandins, Leukotrienes and Essential Fatty Acids, 82, pp. 105109 (2010).

6. Kramer, J.K., Cruz-Hernandez, C., Deng, Z., Zhou, J., Jahreis, G. and Dugan, M.E. "Analysis of conjugated linoleic acid and trans 18: 1 isomers in synthetic and animal products", The American Journal of Clinical Nutrition, 79, pp. 1137S-1145S (2004).

7. Khaskheli, A.A., Talpur, F.N., Demir, A.S., Cebeci, A. and Jawaid, S. "A highly selective whole cell biocatalysis method for the production of two major bioactive conjugated linoleic acid isomers", Biocatalysis and Agricultural Biotechnology, 2, pp. 328-332 (2013).

8. Li, J., Zhang, L., Han, X., et al. "Effect of incubation conditions and possible intestinal nutrients on cis9, trans-11 conjugated linoleic acid production by Lactobacillus acidophilus F0221", International Dairy Journal, 29, pp. 93-98 (2013). 
9. Churruca, I., Fernández-Quintela, A. and Portillo, M.P. "Conjugated linoleic acid isomers: differences in metabolism and biological effects", Biofactors, 35, pp. 105-111 (2009).

10. Adamczak, M., Bornscheuer, U.T. and Bednarski, W. "Properties and biotechnological methods to produce lipids containing conjugated linoleic acid", European Journal of Lipid Science and Technology, 110, pp. 491504 (2008).

11. Ogawa, J., Kishino, S., Ando, A., Sugimoto, S., Mihara, K. and Shimizu, S. "Production of conjugated fatty acids by lactic acid bacteris", Journal of Bioscience and Bioengineering, 100, pp. 355-364 (2005).

12. Ando, A., Ogawa, J., Kishino, S. and Shimizu, S. "CLA production from ricinoleic acid by lactic acid bacteria", Journal of the American Oil Chemists' Society, 80, pp. 889-894 (2003).

13. Ando, A., Ogawa, J., Kishino, S. and Shimizu, S. "Conjugated linoleic acid production from castor oil by $<\mathrm{i}>$ Lactobacillus plantarum $</ \mathrm{i}>\mathrm{JCM} 1551$ ", Enzyme and Microbial Technology, 35, pp. 40-45 (2004).

14. Bligh, E.G. and Dyer, W.J. "A rapid method of total lipid extraction and purification", Canadian Journal of Biochemistry and Physiology, 37, pp. 911-917 (1959).

15. Lin, T.Y., Lin, C.-W. and Lee, C.-H. "Conjugated linoleic acid concentration as affected by lactic cultures and added linoleic acid", Food Chemistry, 67, pp. 1-5 (1999).

16. Chin, S., Liu, W., Storkson, J., Ha, Y. and Pariza, M. "Dietary sources of conjugated dienoic isomers of linoleic acid, a newly recognized class of anticarcinogens", Journal of Food Composition and Analysis, 5, pp. 185-197 (1992).

17. Villaverde, J.J., Santos, S.A., Haarmann, T., et al., "Cloned Pseudomonas aeruginosa lipoxygenase as efficient approach for the clean conversion of linoleic acid into valuable hydroperoxides", Chemical Engineering Journal, 231, pp. 519-525 (2013).

18. Yazdi, Z.K. and Alemzadeh, I. "Improvement of palm oil and sunflower oil blends by enzymatic interestrification", International Journal of Food Science \& Technology, 46, pp. 1093-1099 (2011).

19. Anderson, M.J. and Whitcomb, P.J., RSM Simplified: Optimizing Processes Using Response Surface Methods for Design of Experiments, Productivity press (2005).

20. Gorissen, L., Raes, K., Weckx, S., et al. "Production of conjugated linoleic acid and conjugated linolenic acid isomers by Bifidobacterium species", Applied Microbiology and Biotechnology, 87, pp. 2257-2266 (2010).

21. Coakley, M., Ross, R., Nordgren, M., Fitzgerald, G., Devery, R. and Stanton, C. "Conjugated linoleic acid biosynthesis by human-derived Bifidobacterium species", Journal of Applied Microbiology, 94, pp. 138145 (2003).

22. Kishino, S., Ogawa, J., Omura, Y., Matsumura, K. and Shimizu, S. "Conjugated linoleic acid production from linoleic acid by lactic acid bacteria", Journal of the American Oil Chemists' Society, 79, pp. 159-163 (2002).

23. Corma, A., Iborra, S. and Velty, A. "Chemical routes for the transformation of biomass into chemicals", Chemical Reviews, 107, pp. 2411-2502 (2007).

24. Zhao, H.-W., Lv, J.-P. and Li, S.-R. "Production of conjugated linoleic acid by whole-cell of Lactobacillus plantarum A6-1F", Biotechnology \& Biotechnological Equipment, 25, pp. 2266-2272 (2011).

25. Liu, P., Shen, S.-R., Ruan, H., Zhou, Q., Ma, L.-L. and He, G.-q. "Production of conjugated linoleic acids by Lactobacillus plantarum strains isolated from naturally fermented Chinese pickles", Journal of Zhejiang University Science B, 12, pp. 923-930 (2011).

26. Hou, J., Liu, Y., Wang, Y., et al. "Promoting the production of conjugated linoleic acid by optimizing the fermentation parameters of Lactobacillus sp", Milchwissenschaft, 66, pp. 368-371 (2011).

27. Kishino, S., Ogawa, J., Ando, A., Omura, Y. and Shimizu, S. "Ricinoleic acid and castor oil as substrates for conjugated linoleic acid production by washed cells of Lactobacillus plantarum", Bioscience, Biotechnology, and Biochemistry, 66, p. 2283 (2002).

\section{Biographies}

Zahra Kouchak Yazdi is currently a PhD student in Chemical and Petroleum Engineering at Sharif University of Technology, Iran. She obtained her BS and MS degrees in Chemical Engineering from the Department of Chemical and Petroleum Engineering at Sharif University of Technology. She worked on oils and fats improvement, and functional food production.

Iran Alemzadeh is Professor in the Department of Chemical and Petroleum Engineering at Sharif University of Technology, Iran. Her current research interests include food science-technology and biotechnology.

Manouchehr Vossoughi is Professor of Chemical and Petroleum Engineering at Sharif University of Technology, Iran. His current research interests include environmental biotechnology and nanotechnology. 